\title{
Pedestrian bridges and load testing
}

\author{
Mladen Kustura \\ University of Mostar, Faculty of Civil Engineering, Ph.D C.E. \\ mladen.kustura@gf.sum.ba \\ Goran Šunjić \\ University of Mostar, Faculty of Civil Engineering, Ph.D C.E. \\ goran.sunjic@gf.sum.ba \\ Brigita Šunjić \\ JP Autoceste FBiH d.o.o. Mostar, M.Eng.C.E., s.brigita@jpautoceste.ba
}

\begin{abstract}
Bridges as structures, but also as a symbol, draw the best out of a human, because by connecting two sides, they certainly always connect rather than separate, unite without dividing. The tasks of builders of primal bridges were limited to pedestrian crossings. Those were the first natural or constructed crossings made of fallen trees that were used for the needs of the then users. Today, pedestrian bridges are gaining importance by being constructed not only for communication but also as a modern way of healthy living. Construction of any structure, including a pedestrian bridge, requires its control. All bridges, regardless of their length, width and purpose, have in common that they must be tested. The Regulation on load testing of bridges (JUS U.M1.046) is one of the parts of legislation that must be adhered to. This Regulation defines the test procedures and evaluation of the results of tests on structures. In addition to a brief insight into modern pedestrian bridges, this paper presents practical examples of load testing of pedestrian bridges conducted by the staff of the Faculty of Civil Engineering, University of Mostar.
\end{abstract}

Key words: pedestrian bridges, load testing, deflections, deformations

\section{Pješački mostovi i ispitivanje pokusnim opterećenjem}

Sažetak: Mostovi kao građevine, ali i simbol, izvlače ono najbolje iz čovjeka jer povezujući dvije strane, oni svakako uvijek više spajaju nego razdvajaju, ujedinjuju bez da dijele. Zadaci graditelja prvobitnih mostova bili su ograničeni na pješačke prijelaze. Bili su to prvi prirodni ili izgrađeni prijelazi od oborenih stabala koji su služili za potrebe ondašnjih korisnika. Danas, pješački mostovi dobivaju na značenju gradeći se ne samo kao komunikacija nego i kao moderan način zdravog življenja. Gradnja svake građevine pa tako i pješačkog mosta traži njezino kontroliranje. Svim mostovima bez obzira na njihovu dužinu, širinu i namjenu zajedničko je to da se nad njima moraju provoditi ispitivanja. Pravilnik o ispitivanju mostova pokusnim opterećenjem (JUS U.M1.046) je jedan od dijelova zakonske regulative koji se mora ispoštovati. Kroz ovaj Pravilnik definirani su postupci ispitivanja te ocjena rezultata ispitivanja konstrukcija. Osim kratkog uvida u moderne pješačke mostove u ovom radu su prezentirani praktični primjeri ispitivanja pješačkih mostova pokusnim opterećenjem uz sudjelovanje djelatnika Građevinskog fakulteta Sveučilišta u Mostaru.

Ključne riječi: pješački mostovi, ispitivanje pokusnim opterećenjem, progibi, dilatacije 


\section{INTRODUCTION}

Bridge design is a complex civil engineering and technical task that needs to meet many requirements, not just the technical solution of its load-bearing structure. The existence of a reliable load-bearing structure is an important prerequisite for the existence of a bridge, but it is not sufficient for its use value. In addition to these conditions, bridges, like all other structures, should meet the requirements of functionality, safety, durability, cost-efficiency, aesthetics and ecology (environmental impact). The geometry of pedestrian bridges (level lines, slopes), and especially the curvature of the axis, is much freer than the geometry of solid bridges. Bridge widths are adjusted to the needs of pedestrians and cyclists. They are constant for longer bridges, and expansions at the ends are often designed for shorter ones. The material for construction is selected depending on the length of the bridge, and thus smaller bridges are built of laminated wood and concrete, and longer ones of steel or as a composite steel-concrete structure. Static systems are beam, frame, arch, suspension and cable-stayed. This century, in which we live and in which skyscrapers exceed vertical limits and 3D printers change design and engineering, is full of surprises, so it is no wonder that the construction of bridges follows the new innovative boom. Although the primary function of bridges is to provide passage from point $A$ to point $B$, their structure today is anything but ordinary.

\section{Examples of pedestrian bridges}

In this part of the paper, several achievements of modern construction of pedestrian bridges in the world and in the region will be presented.

\subsection{Charles Kuonen Suspension Bridge, Switzerland}

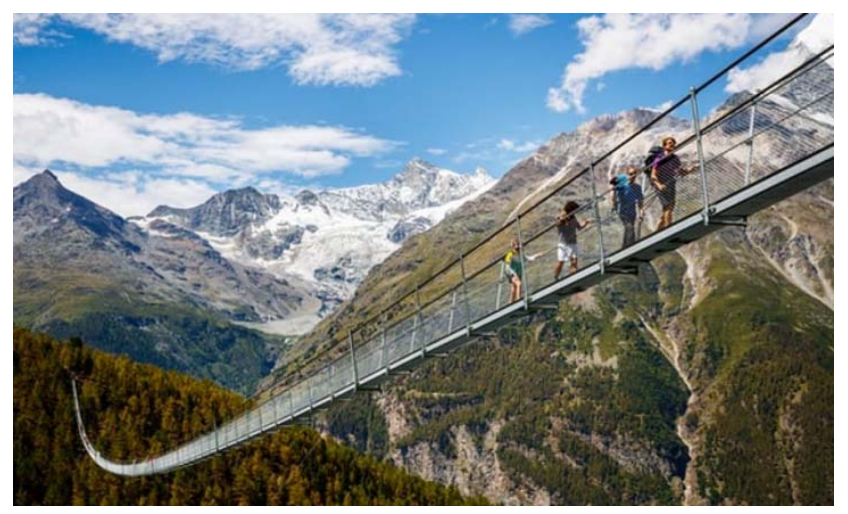

Figure 1. Charles Kuonen Suspension Bridge, Switzerland

Nearly half a kilometer long, the Charles Kuonen bridge in Switzerland, also called the Europe Bridge, is the longest pedestrian suspension bridge in the world, offering visitors a breathtaking walk. The steel-structure bridge was built at an altitude between 1600 and 2200 meters above sea level with a view of the Matterhorn, Weisshorn and the Bernese Alps in the distance. It replaced the previous bridge that was damaged by rockslides. The Swissrope \& 
Kustura, M., Šunjić, G., Šunjić, B.

Pedestrian bridges and load testing

Lauber cable car engineers managed to erect the bridge in just ten weeks. The bridge only $65 \mathrm{~cm}$ wide can be crossed in ten minutes.

\subsection{Sölvesborg Bridge, Ljusarkitektur, Sweden}

Ivesborgsbron or Sölvesborg Bridge is the longest pedestrian bridge in Europe, even 755.90 meters long. It is located in Sweden and connects the town of Sölvesborg with a new modern residential area located across the bay. The striking design of the bridge is enriched by illumination placed on the outside of the structure, where each module highlights cable suspensions and three arches made from 150 tons of steel. The direct light is dimmed and shields that reduce glare and hide its source are installed. Different color sequences are programmed in the LED and change throughout the year.

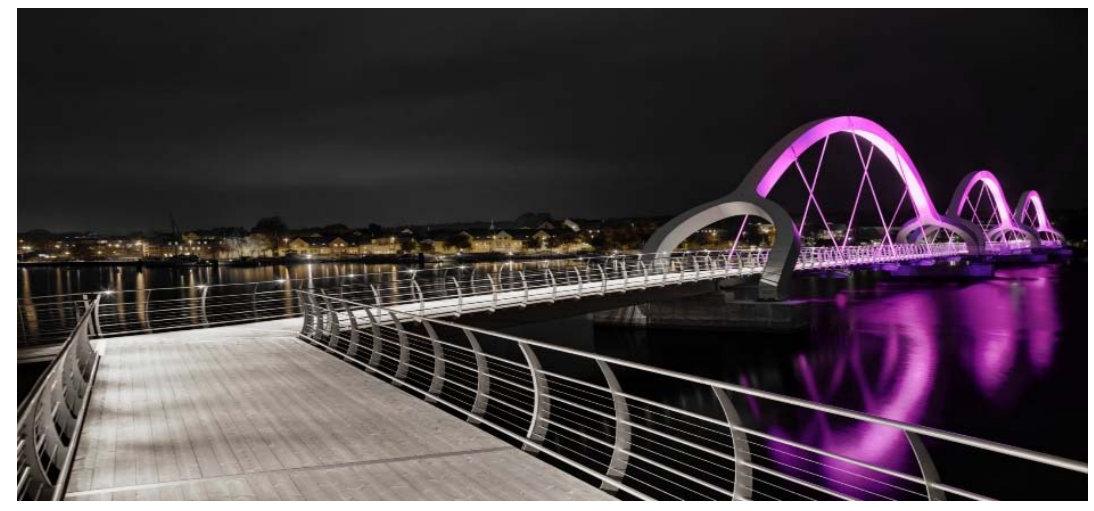

Figure 2. Sölvesborg Bridge, Ljusarkitektur, Sweden

\subsection{Millennium Bridge over the Thames in London, England}

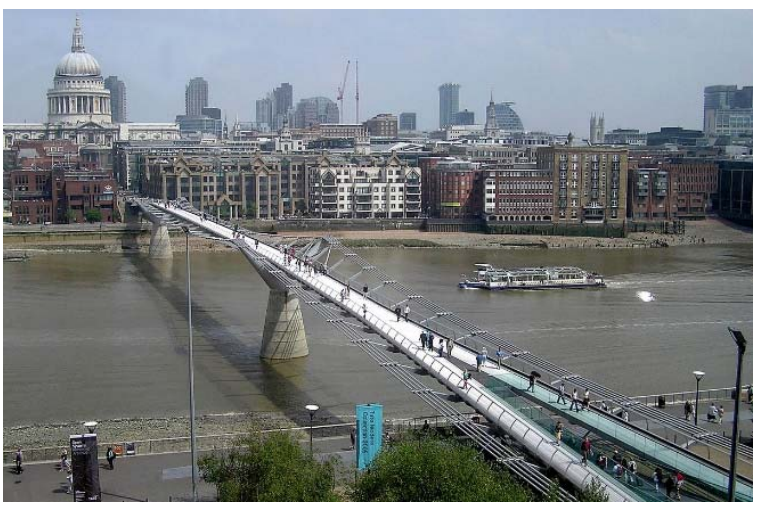

Figure 3. Millennium Bridge over the Thames in London, England

The Millennium Bridge over the Thames in London, England, is a suspension bridge over three spans with shallow load-bearing cables with extremely low rise. The cables pass over the steel "V" pylons continuously and thus achieve a catenary with a low rise and large horizontal force. The lightweight aluminum footway is constructed from two longitudinal pipes at the edges of cross girder sections and bracings of crossed diagonals. The bridge beam is suspended on supporting cables with rigid hangers of variable distance of the contact 
Kustura, M., Šunjić, G., Šunjić, B.

Pedestrian bridges and load testing

surface from the cable grip. In addition to the beautifully shaped piers and the "V" pylons, the bridge also leaves the impression of industrial improvisation. This bridge was built for the needs of tourists and pedestrians who want from St. Paul's Church to visit the new Tate Gallery on the other bank of the Thames.

\subsection{Henderson Waves, Singapore}

Henderson Waves, Singapore, the highest pedestrian bridge in Singapore, is part of a 9-mile chain of green areas extending over three major parks, Mount Faber, Telok Blangah Hill Park and Kent Ridge Park. This unique bridge is 274 meters long and is located at a height of 36 meters. It is undulated in shape and is made of curved steel ribs that function as shelters from the elements or curious eyes. Seats are placed in the shelters. The floor is paved with slats of yellow Balau wood, which grows in Southeast Asia, and heights of individual points of the bridge are marked on them. The bridge is illuminated overnight by popular LED lights that give it a whole new dimension and a different appearance.

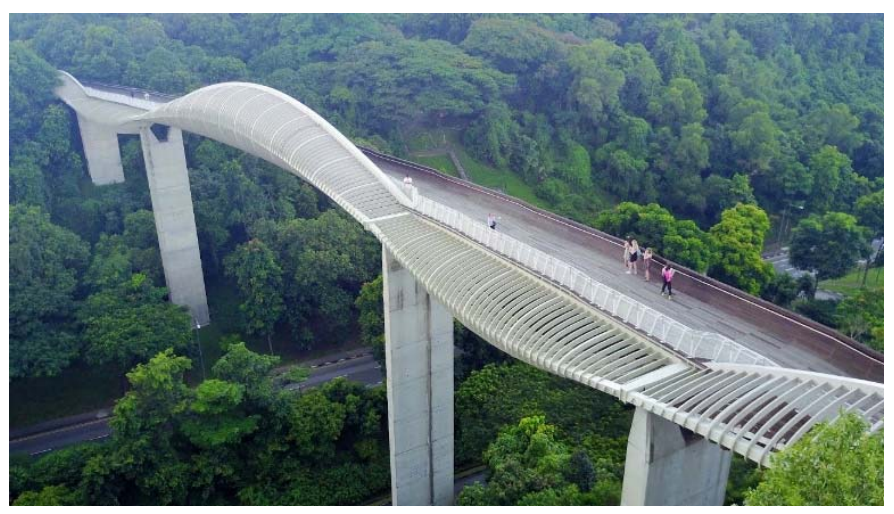

Figure 4. Henderson Waves, Singapore

\subsection{Pedestrian Bridge Shanghai, China - 3D print}

The longest concrete pedestrian bridge in the world was opened in Shanghai. It was built by a team of experts from the Tsinghua University of Architecture in Beijing using 3D printing technology. It is 26.3 meters long and 3.6 meters wide, and is located in Shanghai's Baoshan district. This single-arched bridge was constructed from 176 concrete units that were printed using two robotic 3D printers within 450 hours. Unlike traditional bridges, this one does not contain reinforced concrete. It is made of materials that can withstand sun and rain long enough to meet national construction standards. 
Kustura, M., Šunjić, G., Šunjić, B.

Pedestrian bridges and load testing

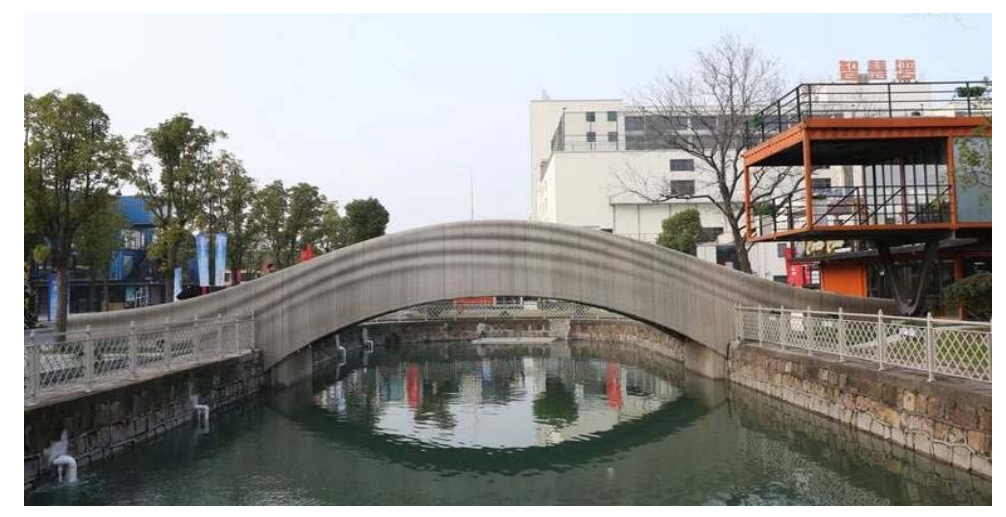

Figure 5. Pedestrian Bridge Shanghai, China - 3D print

The bridge structure consists of 44 hollow units, while the deck is constructed from 68 pavement units filled with white gravel, and the handholds are made from another 64 pieces. All components are printed using polyethylene concrete composites and admixtures. According to expert estimates, compared to the conventional construction process, $33 \%$ of the planned money was saved. Before construction of the bridge began, experts made a smaller model to test the entire project. The purpose of testing is to prove that the bridge can withstand pedestrians passing over it and staying on the bridge. A real-time monitoring system is incorporated into the bridge to monitor any deformations and displacements, and this information will be used to further assist in the development of $3 D$ printing for engineering.

\subsection{Pedestrian bridge (White Bridge, Bridge of Youth), Osijek, Croatia}

Pedestrian bridge (White Bridge, Bridge of Youth), Osijek, Croatia is a suspension pedestrian bridge built in 1980 in just three months, and it instantly became a symbol of the city as the only city's pedestrian bridge $35 \mathrm{~m}$ high and $6 \mathrm{~m}$ wide, like old city bridges. With its 200-meter arched bridge section attached with steel cables to four-part slender riverside pylons, it is a unique structure of Osijek and Croatia. Its central part is reminiscent of the Elizabeth Bridge in Budapest, and the pylons of the Eiffel Tower in Paris. In recent years, padlocks locked by those in love in order to "imprison" their love forever can be found on the bridge more and more often.

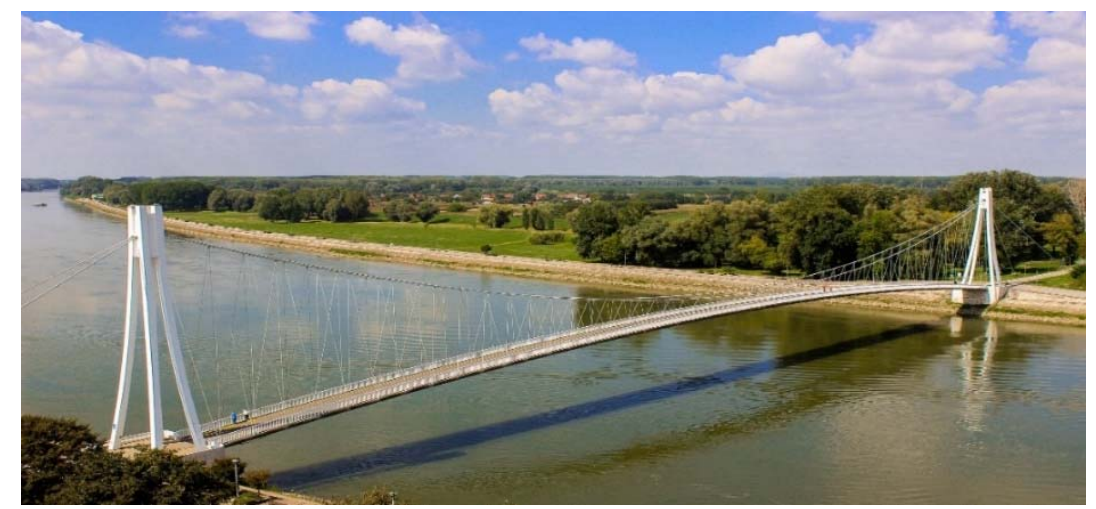

Figure 6. Pedestrian bridge (White Bridge, Bridge of Youth), Osijek, Croatia 
Kustura, M., Šunjić, G., Šunjić, B.

Pedestrian bridges and load testing

\subsection{Saint Irenaeus Bridge, Serbia}

The Saint Irenaeus Bridge in Serbia is a pedestrian bridge over the Sava River between two Mitrovicas, Sremska and Mačvanska. With a total length of 262.5 meters, this is the longest suspension pedestrian bridge in Europe and the longest pedestrian bridge in Serbia and the Balkans. The bridge was opened on 28 June 1994, and the design of this bridge was developed by Serbian academician Nikola Hajdin.

The main structure of the bridge consists of a system of inclined cables. The spans are $35+192.5+35=262.5 \mathrm{~m}$ where the middle value is the span between the pylons (piers). The width of the bridge is only $5.5 \mathrm{~m}$, so this bridge is considered as one of the narrowest bridges with this system in relation to the span. The main beam has a composite cross section with concrete deck and a height of $1.3 \mathrm{~m}$. On the middle (large) span, three cables start from the pylon at the ends of the large span and support the main beam at intervals of 27.5 meters. The cables starting from the pylons are anchored at the ends of the structure at both ends of the cross section. The obelisk-shaped bridge pylons are constructed of reinforced concrete. This bridge also has its most significant point: the bell towers of all three churches in the town can be seen from only one place, however, the place is not marked but tourists have to find it by themselves.

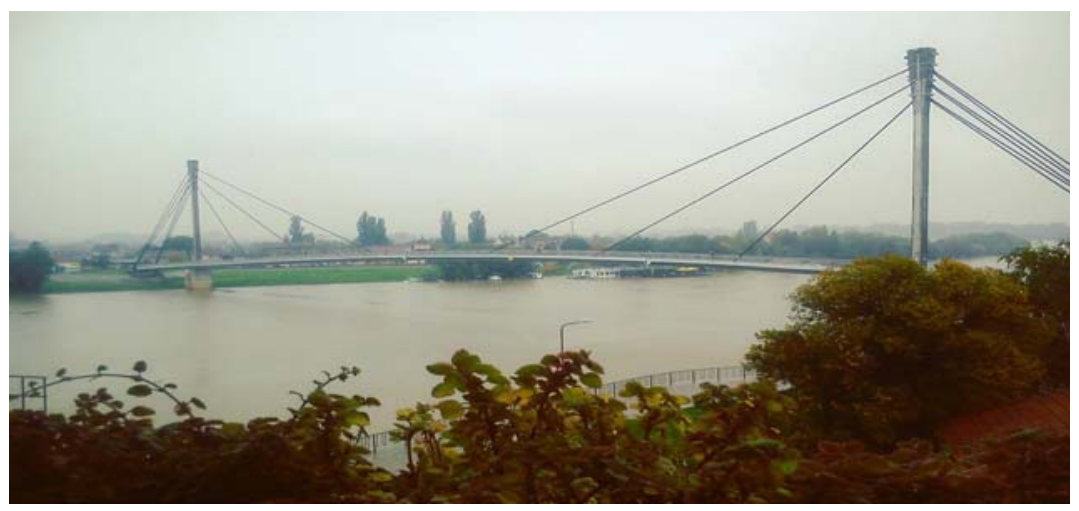

Figure 7. Saint Irenaeus Bridge, Serbia

\section{LOAD TESTING OF PEDESTRIAN BRIDGES}

The goal of building bridges is to connect settlements, villages, cities, states. However, bridges are also demolished and we can distinguish between unintentional and intentional demolition. Unintentional demolition of bridges is usually caused by floods, strong winds or wind gusts, large temperature changes, earthquakes and the like. Intentional demolition of a bridge follows when it is found to be dilapidated, and as such would pose a danger to traffic or if other traffic solutions require construction of a new structure, and the old one is assessed as unusable. Traffic accidents, impacts of water and land vehicles on piers under overpasses result in greater or lesser material damage, and sometimes in human casualties too. From the above it can be concluded that there is a need for continuous monitoring of displacements and deformations of the bridge in order to be able to respond in time in case defects are observed. Load testing of bridges is performed according to the Regulation on load testing of bridges JUS U.M1.046: 1984. 
Kustura, M., Šunjić, G., Šunjić, B.

Pedestrian bridges and load testing

\subsection{Load test}

Load tests can be divided into several types. According to the frequency, into regular and control tests, according to the load size into normal load tests, special load tests and exceptional load tests. Special load tests are applicable in case all requirements from the project are not met and there are doubts about connections and if the structure is not satisfactory even after repeated load test, while exceptional load tests are performed only in case of requirements for loads greater than design load, and results are valid only for that overloading of the bridge e.g. passage of special loads.

Static and dynamic load tests are mandatory for road bridges with spans of 15 or more meters, for railway bridges with spans of 10 and more meters and bridges with special and exceptional load tests regardless of the span. This type of load tests is carried out on a fully completed bridge and it is necessary that no other work is performed on the bridge during the test. According to the duration of loading, they are short-term and long-term tests, and it is important to check measurements of the elements and quality of the installed material before the tests. The activities preceding the tests are, among other things, inspection of the project documentation, a complete testing program that includes the size and arrangement of loads by stages, calculation of expected deformations and deflections, arrangement of measuring points and the testing scheme.

The requirements that the structure must meet are the following:

- The structure and all its elements must be strong and stable in order to be able to carry the planned load;

- The displacements of individual points of the structure must not be greater than the displacements allowed by the conditions of use;

- The structure under load must not be brought to a condition resulting in cracks and damage that reduce the intended mode of operation or shorten service life of the structure.

According to the Regulation on load testing of bridges, it can be taken that the bridge structure is in good operating condition if:

- Measured deflections and displacements are less than or equal to theoretical;

- Measured permanent deflections after unloading are less than $15 \%$ of the maximum measured deflections in the same place for steel and composite bridges, $20 \%$ of the measured deflections for prestressed concrete bridges and $25 \%$ of the maximum measured deflections for reinforced concrete bridges;

- Width of measured cracks for reinforced concrete bridges is less than allowed, in conformity with technical regulations;

- Values of measured deflections are such that they do not affect the functionality or aesthetic appearance of the structure.

In case that the above conditions are not met and the permanent deflections are exceeded up to $25 \%$, it is necessary to repeat the load test, where the permanent deflections must not exceed: $7.5 \%$ of the measured values under load for steel structures, $10 \%$ of the measured values for prestressed concrete bridges, and $12.5 \%$ of the measured values for reinforced concrete bridges.

\subsection{Examples of pedestrian bridge testing}

In many years of their work, employees of the Faculty of Civil Engineering University of Mostar have tested a large number of bridges, including pedestrian ones. As examples, we can single out the tests conducted in Mostar on the newly constructed pedestrian overpass at the northern entrance to the city, then testing of the wooden pedestrian bridge in the Tihaljina town in the Municipality of Grude and testing of the pedestrian bridge in Visoko in 
Kustura, M., Šunjić, G., Šunjić, B.

Pedestrian bridges and load testing

the settlement of Luke-Ozrakovići, and this bridge testing procedure will be analyzed in more detail.

\subsection{Pedestrian bridge at the northern entrance to the City of Mostar}
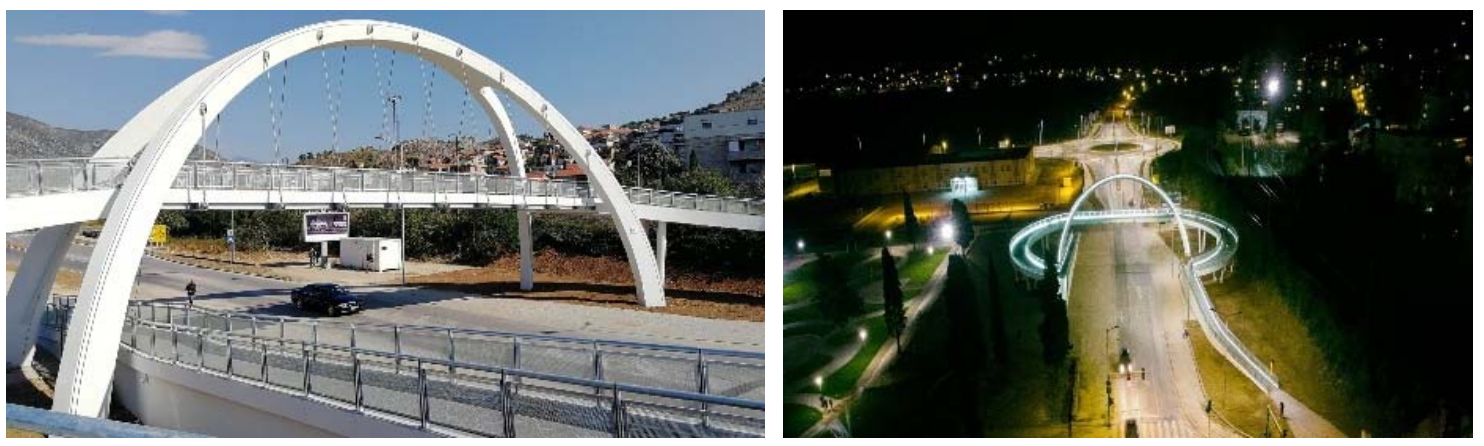

Figure 8. Pedestrian bridge at the northern entrance to the City of Mostar

This pedestrian bridge is located at the very entrance to Mostar on the north side and we can say that it is immediately reminiscent of one of the city's symbols - the Old Bridge. This representative structure, which has both symbolic and aesthetic meaning, primarily serves for crossing of pedestrians, but also for connecting two urban units into one. The crossing itself is designed as a composite structure suspended on a two-part reinforced concrete arch with a span of $30 \mathrm{~m}$. The superstructure is made as a monolithic RC deck $20 \mathrm{~cm}$ thick, supported by steel cross girders HEA 260 which are suspended at the ends from the RC arch. In the longitudinal direction, the cross girders are connected with HEA 220.
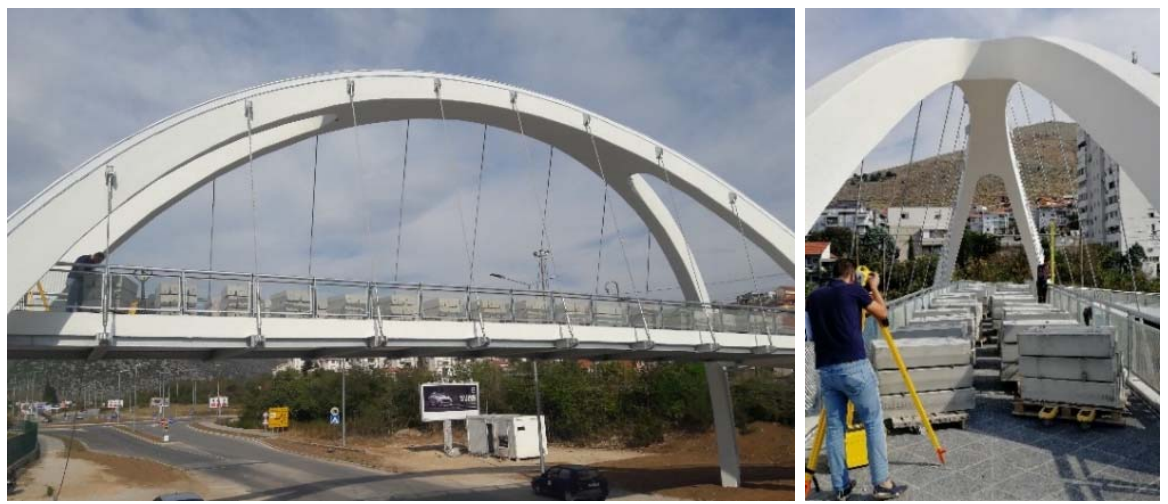

Figure 9. Test load on the bridge

For measuring the deflection on the structure, three measurement points were selected at the points of attachment of the cross girder HEA 260 to the suspension cable; the maximum deflection of $6.5 \mathrm{~mm}$ was measured. In addition, measurements of strains in concrete and steel were carried out at the base of the RC arch and on one steel suspension cable. 
Kustura, M., Šunjić, G., Šunjić, B.

Pedestrian bridges and load testing

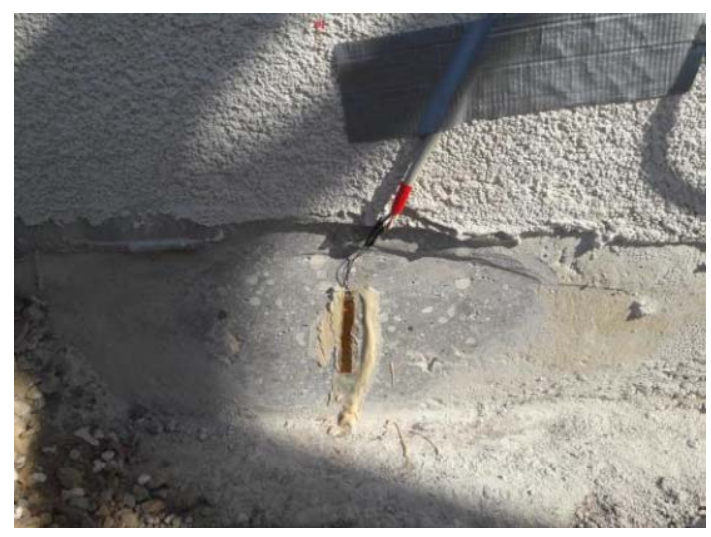

Figure 10. Measurement of strains at the base of the RC arch

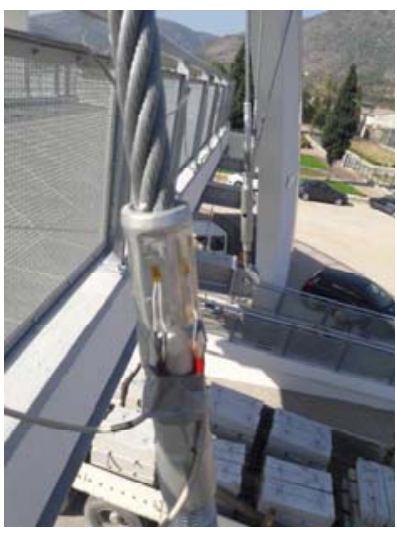

Figure 11. Measurement of strains on one suspension cable

A measurement of the dynamic characteristics of the structure was performed when a hand pallet jack passed over the wooden board, which caused a dynamic impact, i.e. caused excitation of the structure, which continued to vibrate with free vibrations, whose frequencies were measured.

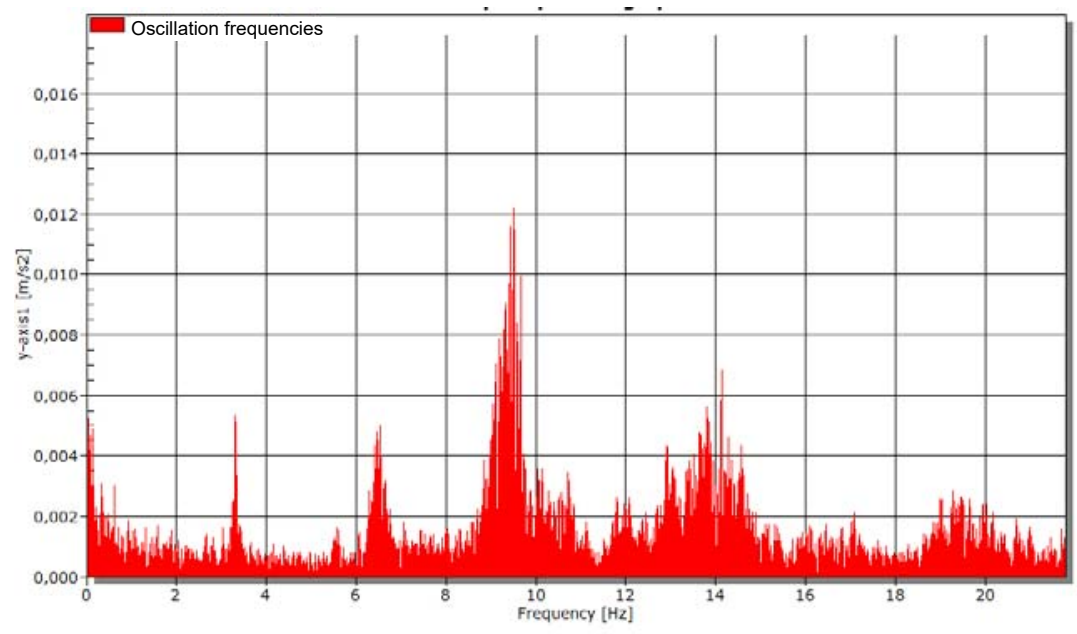

Figure 12. Oscillation frequencies

\subsection{Pedestrian bridge at the Tihaljina River source, Municipality of Grude}

With the construction of an adventure park on the Tihaljina River spring site in the municipality of Grude, an interesting structure of wooden pedestrian bridge with a frame static system was made, with load-bearing elements made of glued laminated wood. 
Kustura, M., Šunjić, G., Šunjić, B.

Pedestrian bridges and load testing

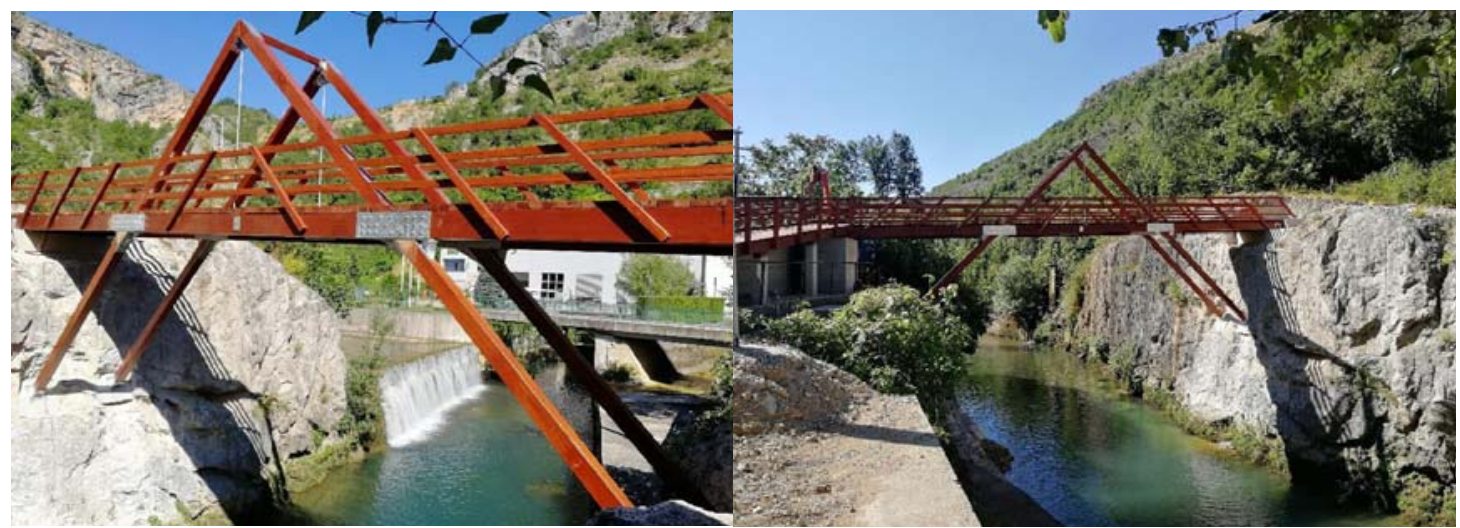

Figure 13. Pedestrian bridge at the spring of the Tihaljina River, Municipality of Grude

The span of the bridge is $18.24 \mathrm{~m}$ and the width is $2.3 \mathrm{~m}$. The frame structure is supported by abutments and by inclined struts that support the bridge structure in the middle third of its span. The footpath is made of $8 \mathrm{~cm}$ thick planks, supported by two main longitudinal girders. A steel suspension cable $\Phi 30$, which connects the top of the inclined strut and main longitudinal girders, is made in the middle of the bridge. The fence of the bridge is also wooden, $100 \mathrm{~cm}$ high. Connections of individual parts of the structure are made with bolts and connecting steel sheets.

The load test was carried out using wooden pallets on which six concrete road curbs $15 / 25 / 100 \mathrm{~cm}$ with individual weights of $90 \mathrm{~kg}$ were placed. The total load was about $5.5 \mathrm{kN}$ per pallet. The pallets were placed next to each other over the entire bridge.
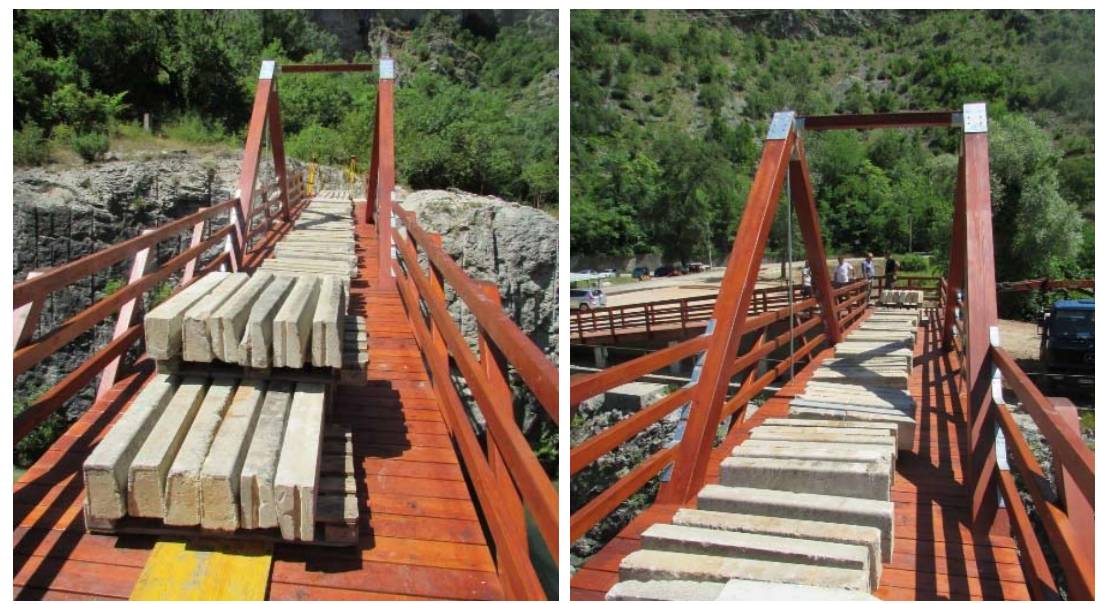

Figure 14. Test load on the bridge

Deflections were measured on the bridge at appropriate measurement points in all fields of the bridge.

The measurement of deflections was performed before, during and after the test loading (unloading). The maximum value of the measured deflection was $2.1 \mathrm{~mm}$.

For the dynamic test, response of the structure to the dynamic excitation caused by jumping of a mass of about $2 \mathrm{kN}$ was measured. The natural frequencies of the bridge structure were determined by measuring the vertical accelerations using an accelerometer installed on the bridge structure. 
Kustura, M., Šunjić, G., Šunjić, B.

Pedestrian bridges and load testing

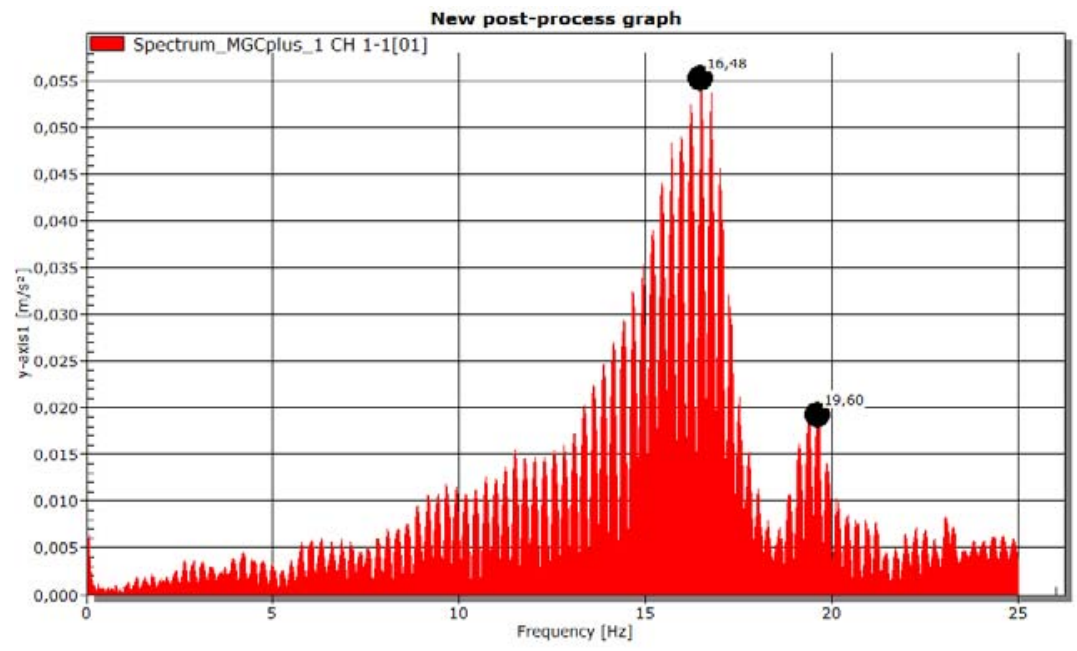

Figure 15. Oscillation frequencies

\subsection{Pedestrian bridge in Visoko}

Employees of the Faculty of Civil Engineering University of Mostar tested the new pedestrian bridge over the Bosna River in Visoko in May 2017. The bridge connects two settlements, and is special for its lighting and appearance. It is a technically challenging pedestrian bridge, because it spans the Bosna River, and the construction site, construction type, materials, technical and technological solution, aesthetic design, details, calculations of stability and resistance are made according to state-of-the-art professional and world standards.

The cable-stayed system of the bridge consists of a reinforced concrete superstructure, concrete pylon and inclined high-strength steel stay cable. Three cables that connect the superstructure with sections $13.25 \mathrm{~m}$ for the first cable, $13 \mathrm{~m}$ for the second cable and $13 \mathrm{~m}$ for the third cable are designed on the right side of the pylon, while three parallel cables at the axis distance from the pylon of $13.43 \mathrm{~m}, 14.23 \mathrm{~m}$ and $14.78 \mathrm{~m}$ are installed on the left side of the pylon. Anchoring of stay cables is performed through steel sheets concreted into the superstructure and the pylon and into the concrete rib on the abutment.

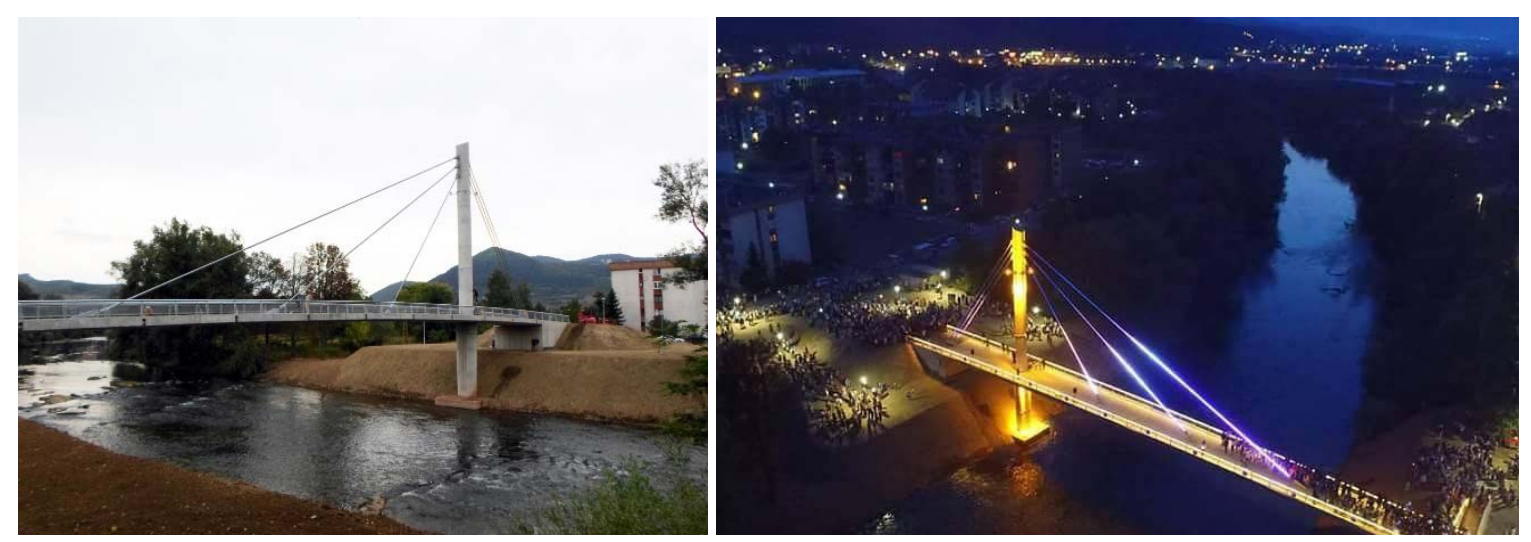

Figure 16. Pedestrian bridge in Visoko 
Kustura, M., Šunjić, G., Šunjić, B.

Pedestrian bridges and load testing

The abutment on the left bank is designed in reinforced concrete C $25 / 30$, steel B500B as a "U" section with the front wall $1.30 \mathrm{~m}$ in thickness and parallel wings $0.35 \mathrm{~m}$ in thickness. The abutment body together with standing wings rests on the foundation slab with plan dimensions $6.70 \times 6.40 \mathrm{~m}$ and thickness $1.30 \mathrm{~m}$, and over four drilled piles $\varnothing 100 \mathrm{~cm}$ at axis-to-axis distance of $4.50 \mathrm{~m}$ in a layer of substrate. The abutment is designed as a support for the superstructure and as part of the access ramp from the direction of Luka settlement towards the bridge. A $0.70 \mathrm{~m}$ wide and $4.70 \mathrm{~m}$ long rib, which will be used for anchoring the cables, is designed in the axis of the abutment that coincides with the bridge axis.

\subsubsection{Testing method and load}

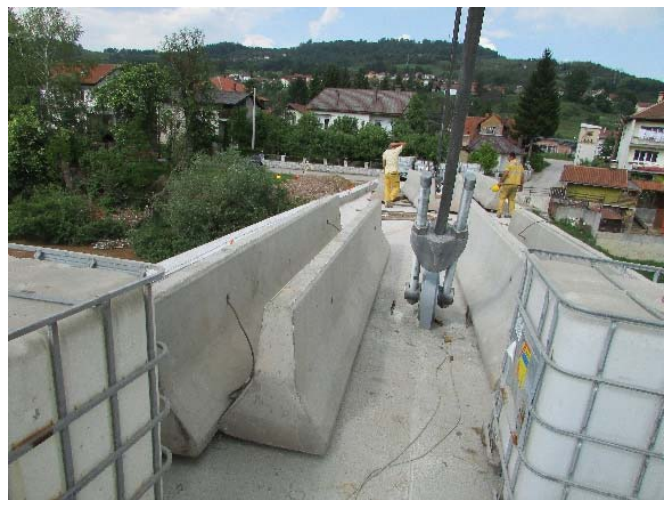

Figure 17. Test load

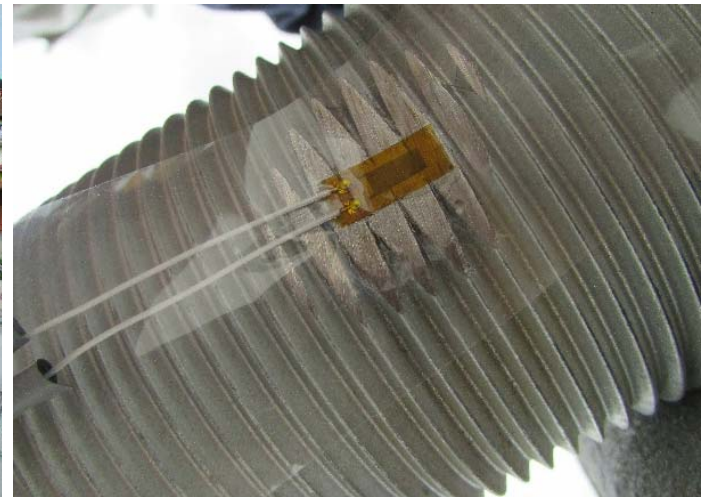

Figure 18. Measurement tape for steel

Deflections in bridge fields were measured at appropriate measurement points on the bridge, while the relative deformations of steel were measured on steel bolts of stay cables in the larger field, since it is impossible to measure deformations of wire stays with measuring tapes. The deformation of concrete on the underside of the bridge deck was measured only in the section of the larger field of the bridge where bending moments and deflections of the bridge are greatest. The deflection measurement was performed geodetically. The dynamic response of the structure to excitation caused by the impact of a concrete barrier against the bridge was also measured on the bridge.

The test loads were made of containers filled with water and concrete traffic barriers of known weight. The load test was carried out with three types of loads placed in the positions in which they cause the maximum stress in bridge fields and stay cables. The first type of load consists of 4 precast concrete traffic barriers $5 \mathrm{~m}$ long. The second type of load consists of 20 plastic containers with a volume of $1 \mathrm{~m}^{3}$ filled with water. The third type of load consists of 4 concrete barriers and 2 containers.

The bridge calculation was performed in the program Tower 7.0, and based on the obtained results of load tests and the calculation model, a comparison was made and the conclusion was given.

\subsubsection{Test results}

Measurements of strains were performed at a total of five measurement points, and the effects of static load on the RC superstructure (measurement point 5 ), steel stay cable (measurement point 3 ) and the dynamic response of the bridge structure on excitation will be shown as test results due to the limited number of pages in this paper. 
Kustura, M., Šunjić, G., Šunjić, B.

Pedestrian bridges and load testing

The measurement of strains for steel and concrete was performed with HBM measurement tapes, while the measurement of structural response to dynamic excitation by registering acceleration was performed by acceleration pickup i.e. by the uniaxial accelerometer made by HBM company, type B12/500. The measured values were collected by the MGC plus system and the measured values were processed in the Catman AP program package. An electronic level instrument type Leica Sprinter 150M was used for geodetic surveying.

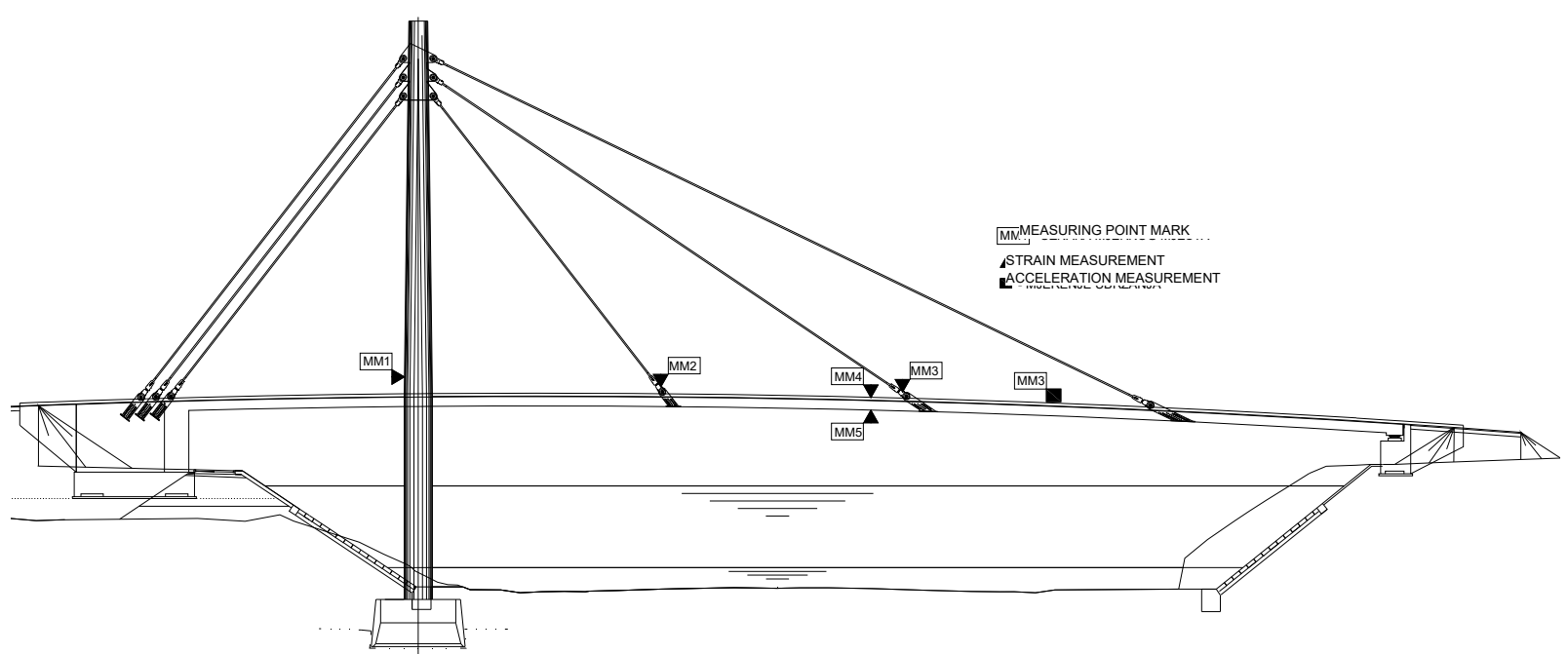

Figure 19. Schematic arrangement of measurement points

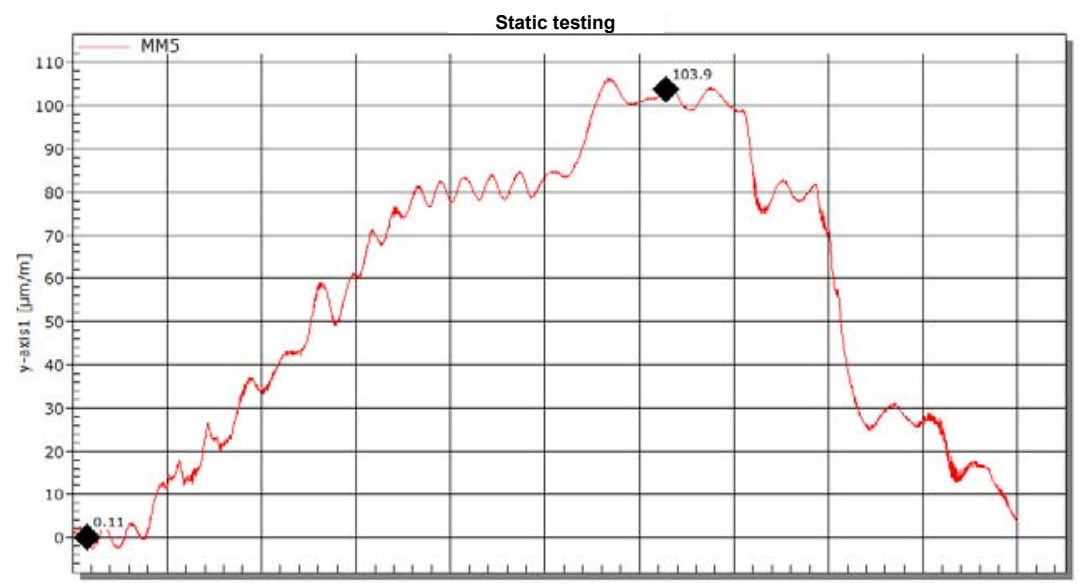

Figure 20. Strain for the measurement point 5 - concrete deck 
Kustura, M., Šunjić, G., Šunjić, B.

Pedestrian bridges and load testing

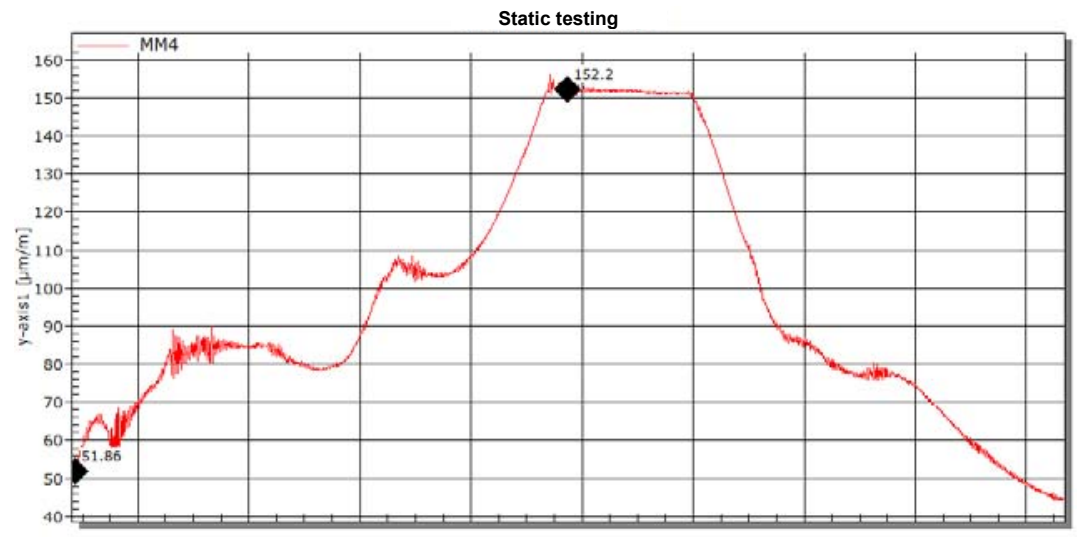

Figure 21. Strain for the measurement point 3 - steel stay cable

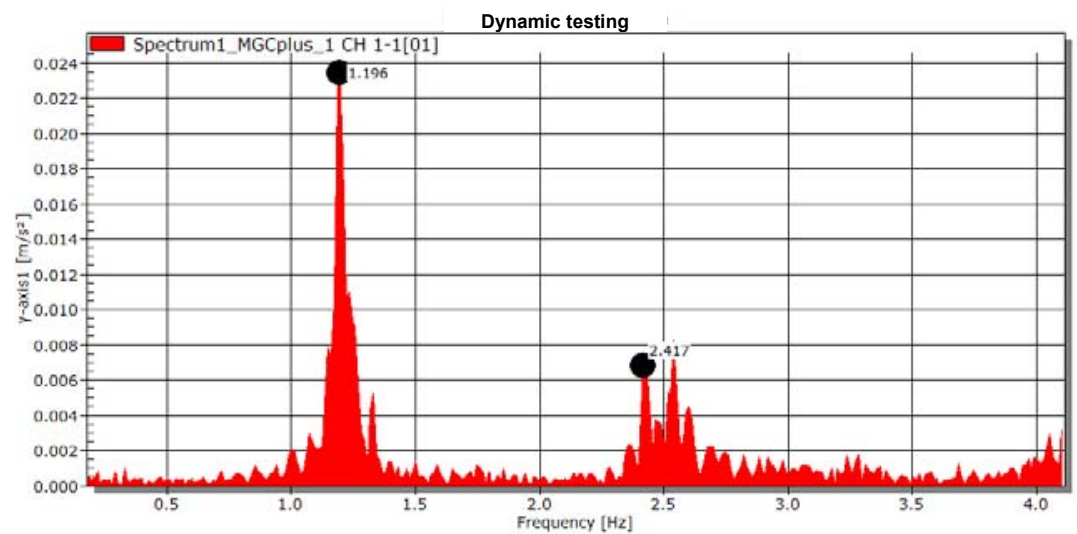

Figure 22. Bridge oscillation frequencies

Comparing the results obtained by load testing the bridge, or geodetically measured deflections, where the maximum value of deflection measured during the test was $2.1 \mathrm{~mm}$ and the calculation deflection at the same measuring point was $2.08 \mathrm{~mm}$, and measured strains and oscillation frequencies of the bridge with the values obtained by calculation in the Tower 7.0 software, it was concluded that the tested bridge performs in accordance with the calculation models and has the necessary safety for the designed load and can serve the intended purpose.

\section{CONCLUSION}

The impressiveness, beauty and longevity of structures built throughout history still capture the attention of the scientific profession and the wider community. For some of the methods and calculations used by the designers at a time when there were no modern mathematical models and tools and ways to control the constructed structures, we can say that they are still largely unknown. Also, throughout history, we have borne witness to a number of disasters, and so conducting controls and testing what has been built suggest themselves as a matter of course. An important segment in this whole series is load testing, which can give us a complete insight into the condition of the tested structures, especially bridges, whether they be road, rail or pedestrian bridges. Practical knowledge of the actual bearing capacity, stability, development and magnitude of deformations as well as other static and dynamic 
Kustura, M., Šunjić, G., Šunjić, B.

Pedestrian bridges and load testing

parameters is the basic goal for testing of bridges and other structures. The scope of testing is determined depending on the geometric and calculation characteristics of the tested structure, and the legal regulations, as a combination of experience and science, indicate which structures should be tested. Comparison of the obtained experimental results with the calculated ones is performed in order to verify the calculation models and determine the quality of construction of the tested structure. This paper briefly presents the methods of load testing of pedestrian bridges, conducted by employees of the Faculty of Civil Engineering University of Mostar in order to determine the relevant static and dynamic parameters.

\section{REFERENCES}

1. Pržulj, M., Mostovi, Udruženje Izgradnja Beograd, Beograd 2014.

2. Popović J., Đuranović N.: Aktuelne metode ispitivanja mostovskih konstrukcija - dio 1 (Current methods for testing bridge structures - Part 1)

3. Pravilnik o ispitivanju mostova pokusnim opterećenjem JUS U.M1.046:1984.

4. Kapović, Z. (1994): Analiza rezultata mjerenja pomaka mosta preko Pazinske jame, Geodetski list, 4, pp. 361-368.

5. Rak, M., Krolo, J., Bartolac, M.: Ispitivanje i analiza parametara velikih lučnih mostova (Testing and analysis of parameters for big arch bridges), Građevinar 62 (2010) 10, 913-920

6. Biondić, H., Pokusno opterećenje mostova, Ekscentar, No. 14, pp. 80-83, (2011)

7. Glibić M.; Kustura M.: Report on testing of the pedestrian bridge over the Bosna River in Visoko, the settlement of Luke-Ozrakovići

8. Glibić M.; Kustura M.: Report on testing of the pedestrian bridge on the source of the Tihaljina River, Grude Municipality

9. Popović, J., Đuranović, N.: Aktualne metode ispitivanja mostovskih konstrukcija - dio 2 (Current methods for testing bridge structures - Part 2)

10. Rahimić $Đ .:$ Report of testing of the grade-separated pedestrian crossing, the settlement of Zalik - Zalik School, Mostar, 2018.

11. HBM test and measurement, http://www.hbm.com/ 